\title{
Slik kan helsesøstre oppdage og forebygge psykiske plager hos ungdom
}

Mange skoleelever har symptomer på depresjon, men signalene kan være vanskelig å tyde. Det er derfor viktig å være oppmerksom på endringer i følelsesuttrykk og funksjonsnivå.

\section{Forfattere}

\section{Tove Ingeborg Sand}

Helsesøster

Høyskolen Diakonova

\section{Lisbeth G. Kvarme}

Helsesøster og professor

Høyskolen Diakonova

\section{Nøkkelord}

Ungdom Psykisk helse Helsesøster

Sykepleien 2018 106(70421)(e-70421)

DOI: https://doi.org/10.4220/Sykepleiens.2018.70421

\section{HOVEDBUDSKAP}

Ungdoms selvrapporterte psykiske helse viser at mer enn 20 prosent av elevene på ungdomsskolen har psykiske plager. Funn viser at det kan være vanskelig å oppdage at ungdom ikke har det bra fordi de ofte skjuler det. Nedstemtheten kan påvirke deres helse og evne til å følge opp skolen. Tidlig intervensjon, tett oppfølging og tverrfaglig samarbeid kan forhindre at en psykisk vanske utvikler seg til psykisk lidelser. 
Den siste nasjonale Ungdata-undersøkelsen (2016) viser at én av fire til fem elever i ungdomsskolen har følt seg ulykkelig, trist eller deprimert. 82 prosent av elevene besvarte undersøkelsen (1). Andre undersøkelser viser at på ethvert tidspunkt har 15-20 prosent av barn og unge i Norge psykiske vansker i form av atferdsproblemer, angst og depresjon. Symptomene er så tydelige at de går ut over trivsel, læring, daglige gjøremål og samvær med andre (2).

Angst og depresjon er de mest utbredte vanskene/lidelsene generelt i samfunnet og forekomsten øker i ungdomsalderen. Angst og depresjon er lettest og mest lønnsomt å forebygge. Forebyggende tiltak og tidlig intervensjon i den kommunale primærhelsetjenesten vil kunne forkorte sykdomsforløp og redusere utbredelsen av sykdom og funksjonstap (3-5).

Risikofaktorer for å utvikle psykiske vansker hos individet beskrives, av Major og medarbeidere, som lav selvfølelse, manglende opplevelse av kontroll over eget liv og manglende mestringsevne. Mobbing er en sterk risikofaktor for psykiske problemer hos barn og unge. Innsats for å fjerne risikofaktorer vil derfor kunne forebygge utvikling av psykiske vansker og lidelser (4).

\section{Tidlig håndtering}

Selv lette psykiske problemer kan gi større risiko for psykisk sykdom senere i livet (6). Derfor må psykiske vansker håndteres tidlig. Tidlig oppdagelse er et mål og forebygging er et førende prinsipp i Samhandlingsreformen $(3,7)$. 
Dersom forebygging skal få stor effekt, må hovedinnsatsen rettes mot arenaer utenfor helsevesenet, fordi helse i stor grad blir påvirket av forhold som ligger utenfor helsetjenestens kontroll (4). For barn og ungdom er det her snakk om skolen. Forebygging betyr i praksis å redusere antall nye tilfeller av sykdom før de oppstår (8). Ifølge nye retningslinjer for skolehelsetjenesten bør helsesøster konsentrere seg om å oppdage psykiske plager og lidelser hos barn og ungdom som et ledd i det helsefremmende og forebyggende arbeidet (9).

Studien er kvalitativ og det er gjort tre fokusgruppeintervjuer av ni helsesøstre som jobber på ungdomsskolen. For å analysere data ble Kvales tre nivåer av fortolkning benyttet.

\section{TRE HOVEDTEMAER}

Ut fra analysen var det tre hovedtema som ble identifisert ut i fra intervjuene:

- Det er vanskelig å oppdage depressive symptomer hos ungdom

- Konsekvenser av vanskene ved depressive symptomer

- Tverrfaglig samarbeid og tilrettelegging for elever med depressive symptomer.

\section{Resultater og diskusjon}

Helsesøstrene forteller at det kan være vanskelig å fange opp depressive symptomer hos ungdom fordi de ofte skjuler at de strever overfor omgivelsene. De «setter på seg en maske og et smil». Ungdom er i en brytningsfase og noe av symptombildet kan oppfattes av omgivelsene som normale tenåringssvingninger. Det er viktig å se etter endringer hos ungdommer for å fange opp tidlige symptomer på nedstemthet. En av informantene sier: 
«Og så tenker jeg ... det med ungdommer og depresjon ... de kan ofte smile. De kan være glad utad på en annen måte enn voksne, at det mer er sånn amperhet, tomhet eller ... De har kanskje også mer problem med å kommunisere helt hvordan de har det.

Og utad så kan det se veldig sånn vanlig og greit ut.»

\section{Bli kjent med elevene}

Informantene møter mange ungdommer med depressive symptomer på ungdomsskolen. Det er flere måter å fange opp ungdom som er nedstemte. En helsesøster forteller:

«Det er liksom mange forskjellige kanaler. Noen er jo de vi fanger opp i 8.-klassegruppene, noen får vi via lærere eller sosiallærer, noen elever kommer selv, banker på døra og en god del kommer fra foreldre, som tar kontakt fordi de er bekymret for ungdommen sin av en eller annen årsak. Jeg får en del mail og telefoner».

Det er viktig å bli kjent med elevene i starten av ungdomsskolen. På 8. trinn kan elevene fylle ut opplysninger om egen helse via et helseopplysningsskjema og helsesøster kan bli litt kjent med elevene og innkalle til en samtale. På 8 . trinn får elevene også tilbud om å delta i helseopplysningsgrupper. I gruppene - som er for alle elever - informerer helsesøster om helse generelt og om hva elevene kan gjøre hvis de har problemer og hvem de kan henvende seg til.

\section{Åpen $\mathrm{d} ø \mathbf{r}$}

Helsesøstrene er opptatt av å være tilgjengelig og ha en «åpen dør» for å kunne fange opp elever med psykiske vansker. Mange elever kommer på «drop-in» eller en venn av dem kommer og er bekymret. En informant sa: 
«Mange elever som kommer med «vondter», kommer

gjerne for noe underliggende. De kan bruke lang tid på å bli kjent før de tør å fortelle om det som er mest sårbart.»

Det er viktig å være tilgjengelig akkurat når ungdommen trenger det. Hvis en elev endelig har tatt mot til seg og kommer for å prate om det som er vanskelig, kan det være at eleven ikke kommer tilbake dersom døren er stengt eller om han/hun blir bedt om å komme tilbake senere.

\section{三 «Det er lettere for mange å ta kontakt for fysiske plager enn for psykiske vansker.»}

Det er lettere for mange å ta kontakt for fysiske plager enn for psykiske vansker. En helsesøster sier det på denne måten:

«For dem som har slått seg, de går ofte bare rett inn og sier: Hei! Jeg har slått meg her eller der. Mens for dem som strever, de titter kanskje litt mer forsiktig inn og sier: 'Er du ledig nå? Passer det? Jeg skulle så gjerne hatt ...». Du ser det litt egentlig på hele kroppsspråket i døren der, at de liksom kikker inn og øynene flakker litt i døråpningen, titter inn og ser seg kanskje litt over skulderen; 'er det noen bak meg?’».

Informantene sier at de ser en forskjell på de elevene som har noe konkret de ønsker hjelp til og på de elevene som strever psykisk. Helsesøstrene forteller at de fanger opp ungdommenes signaler på at de strever. De snakker om «den tause kunnskapen» som utvikles etter lengre erfaring $\mathrm{i}$ arbeidet med ungdom $\mathrm{i}$ skolehelsetjenesten.

\section{Se etter endringer}


Informantene sier at man må se etter endringer hos ungdommene for å fange opp tidlige symptomer på nedstemthet. Vanlige tenåringsproblemer kan være humørsvingninger, irritabilitet, rot og forglemmelser, impulsivitet og manglende konsentrasjonsevne (10). Humørsvingninger som sinne, tristhet og irritabilitet er vanlig ved depressivitet. Det er to generelle trekk omgivelsene skal være obs på dersom de blir bekymret for en ungdom; hvor store humørsvingningene er og endringer i funksjonsnivået (10).

Andre atferdsendringer kan også være at ungdommene kan oppleve en stor grad av følsomhet for kritikk kombinert med fysiske symptomer som hodepine, verk i kroppen, kvalme eller andre ubehag. Videre kan det være endringer i sove- og spisevaner eller tendenser til å utagere mer enn vanlig, ta større risiko og tilbringe mindre tid sammen med venner og familie.

Hvis atferdsendringene varer i mer enn to uker er det grunn til å bli bekymret og til å handle. Jensen presiserer at ved enhver bekymring for at tenåringen gjennomgår plutselige eller gradvise forandringer, må tenåringen fanges opp og få hjelp (10).

\section{Hemmer elevene}

Mange ungdommer er stresset og helsesøstrene beskriver at de kan ha symptomer som søvnvansker, bekymringstanker, konsentrasjonsvansker, fysiske plager og ensomhetsfølelse. Den kvantitative undersøkelsen til Young \& Dietrich viser til at stress, bekymringer og negative tanker spiller en rolle ved utviklingen av depressive symptomer (11). Young og Dietrich har undersøkt stressende livshendelser hos ungdom og ser en tydelig sammenheng mellom stress og depresjon hos ungdom (12).

På 8. trinn kartlegges ungdoms helse gjennom et helseskjema. Dette samsvarer med forskning på tidlig intervensjon, hvor det anbefales kartleggingsskjemaer for å kunne fange opp tidlige symptomer på depresjon (13). 
Informantene erfarer at nedstemthet hemmer elevene fra å utnytte sitt fulle potensial. De kan få fysiske symptomer, endringer i følelseslivet, sitt sosiale liv, kognitive forandringer og de klarer ofte ikke å følge opp (skole)hverdagen slik de gjorde før. En av informantene beskriver hvordan nedstemthet påvirker livet til ungdom:

«Ja, det tenker jeg, at man ikke klarer å leve det livet man vanligvis lever. Det påvirker din daglige fungering. At du har et så stort symptomtrykk at det påvirker hva du greier å utføre. Da er det ganske alvorlig. Noen symptomer, som å ha det litt kjipt, det har vi alle. Men når det begynner å påvirke deg til å ikke greie å komme deg opp om morgenen, eller du mangler initiativ, trekker deg bort, isolerer deg, ikke klarer å følge opp det daglige programmet ditt, da har det gått for langt».

\section{Trekker seg tilbake}

Helsesøstrene er opptatt av at det er lite som skal til før ungdommene får problemer med å følge opp de daglige gjøremålene, slik de gjorde før. Dersom elevene ikke lenger klarer å leve opp til forventninger på skolen og sosialt, beskriver en av helsesøstrene at ungdommene resignerer:

«Når de ikke klarer å henge med i det som er forventet, trekker de seg tilbake, og så tar det så mye av tankeenergien. Så jeg ser at de bruker mye energi på å henge med på det faglige, det sosiale i fritida og når de da kjenner at det indre ikke stemmer med alt det som forventes av det ytre, så blir de resignert.»

\section{«Flere av ungdommene får problemer med å sette ord på ting i det sosiale.»}


Det kan være krevende for ungdom generelt å forholde seg til alt som skjer sosialt, på skolen, på nett og på fritiden. Dersom en ungdom er nedstemt, kan det bli mer utfordrende sosialt fordi ungdommen får nedsatt funksjon. Mange ungdommer kan trekke seg tilbake fra det sosiale. Og de orker ikke å være så mye sammen med venner og familie som før. Flere av ungdommene får problemer med å sette ord på ting $\mathrm{i}$ det sosiale og faglig og de får et annet følelsesuttrykk.

Å ikke finne ord og kunne forklare seg, kan forsterke ungdommers opplevelse av utilstrekkelighet og sårbarhet. Én helsesøster sier følgende:

«Og så er det mange av dem som kommer som faller litt utenfor sosialt, da. Som strever litt med strategier ofte. Noen med sinnemestringsproblemer eller det kan være at de har litt vansker med å gjøre seg forstått og vansker med å uttrykke seg og så blir det veldig misoppfattet.»

\section{Gutter vs. jenter}

Dersom eleven får problemer med det sosiale på skolen, kan dette medføre at de ikke føler seg trygge og at de ikke trives. I tillegg er det vanskelig å være i en setting der de må forholde seg til så mye hele tiden. De blir slitne av alle inntrykkene og trekker seg unna.

Informantene sier at de tror nedstemthet hos gutter er vanskeligere å oppdage enn hos jenter. Gutter tar ikke kontakt og de forteller ikke om tristhet på samme måte som jenter gjør. Helsesøstrene sier at det kan vises på en annen måte hos guttene - ved en indre uro som kan gi symptomer i form av sinne og aggressivitet eller ved passivitet og apati. Gutter som har depressive symptomer kan oppleves mer avflatet følelsesmessig. En av helsesøstrene beskriver det slik: 
«Jeg har for eksempel aldri møtt en gutt som har drevet med selvskading ... veldig mange jenter ... med kutting og sånn, på skolen hos meg. Gutter som har depressive symptomer som bare isolerer seg hjemme med pc-en. Så jeg opplever, hvis jeg kommer i kontakt med dem, så er de mye mer avflatet følelsesmessig og er litt sånn ... nei, jeg orker ikke, jeg greier det ikke, jeg fikser det ikke ... og sånn ... apati, dette går faktisk ikke, så da blir jeg heller hjemme».

Fravær fra skolen kan være en indikasjon på at eleven har nedsatt funksjon på grunn av nedstemthet.

\section{Større sårbarhet}

Informantene erfarte at ungdommene ikke lenger klarte å følge opp hverdagen slik de gjorde før de ble nedstemte. Mange ungdommer kan oppleve at det sosiale livet blir mer utfordrende å forholde seg til, og de blir mer engstelige. Dette kan bidra til at elevene gruer seg mer for å vise seg frem, for eksempel i gym og om de skal fremføre noe.

Forskning viser at ungdom med depressive symptomer også får symptomer på angst. Det er en komorbiditet mellom disse symptomene og at de fleste ungdommer hadde symptomer både på angst og depressivitet (4, $14,15)$. Skolen er en arena hvor ungdom hele tiden skal prestere og bli vurdert faglig, i tillegg til at de skal fungere sosialt. Dette kan være svært utfordrende i en sårbar fase i livet. 
Helsesøstrene forteller at gutter sjelden tar kontakt selv. Og hvis de får kontakt med dem, har de gjerne gitt opp. De sitter mye hjemme og bruker tid på dataspill. Helsesøstrene forteller også at gutter kan ha et annet uttrykk ved nedstemthet. De kan vise mer sinne og aggresjon og/eller er mer avflatet følelsesmessig når de er depressive. Dette samsvarer med forskning om menns uttrykk ved depresjon, hvor det vises til at menn oftere reagerer med sinne, selvdestruktivitet, mental flukt, stoffbruk, spilleproblemer, søvnproblemer, kvinnejakt og arbeidsnarkomani.

\section{Maskerer følelser}

Studien viser til at det kan hende at menn i større grad enn kvinner maskerer følelser, som nevnt ovenfor (16). TOPP-studien er en longitudinell studie som undersøker utviklingsveier til alkoholforbruk. Det forskes på forhold som trivsel, god psykisk helse og psykiske plager hos barn og ungdom i Norge. Forskningen viser at ungdom har betydelige symptomer på depresjon.

I studien scorer gutter på lik linje med jenter når det gjelder uro og konsentrasjonsvansker. Mellom 24 og 43 prosent av begge kjønn kjenner seg godt igjen i beskrivelser som rastløshet, distraherbarhet eller uro. På spørsmål om depresjon der spørsmålene handler om tristhet, ensomhet og om å gråte, scorer dobbelt så mange jenter enn gutter på dette (3). Ungdomsundersøkelsen fra NOVA har ikke spørsmål om for eksempel irritabilitet, sinne og store humørsvingninger/atferdsendringer (1).

\section{三 «Selvmordsraten hos gutter er dobbelt så høy som hos jentene.»}


Spørsmålet er om man klarer å fange opp guttene i disse undersøkelsene. Det er guttene som i stor grad faller fra skolen (17) og som takler depresjoner dårligere (18). Selvmordsraten hos gutter er dobbelt så høy som hos jentene (19).

\section{Samarbeid og tilrettelegging}

De viktigste samarbeidspartnerne på skolen er (kontakt)lærerne og rådgiver. Skolehelsetjenesten er helt avhengige av et samarbeid med dem som jobber på skolen for å fange opp og hjelpe elever som er nedstemt. Helsesøstrene snakker med mange lærere som er bekymret for hvordan elevene har det.

Elevene trenger tettere oppfølging, tilrettelegging og at de må bli ivaretatt både faglig og personlig når ting begynner å bli vanskelige. De trenger hjelp til å strukturere hverdagen - både på skolen og på fritiden for å komme seg gjennom en krevende fase i livet. Det innebærer samtaler og et tett samarbeid mellom skole, helse og foresatte og eventuelt andre instanser som for eksempel utekontakter og BUP.

Tilrettelegging på skolen kan være å redusere lekser, prøver og å slippe muntlige fremføringer for en periode. Det kan også være å få muligheten til å ta en eller flere pauser i løpet av skoledagen. Det er også viktig med et samarbeid med foreldre for at de skal forstå hvordan ungdommen deres har det og for tilrettelegging hjemme og på fritiden, ved for eksempel å redusere program som treninger og liknende. Man må også ta høyde for at ungdom trenger å kople ut og hvile.

\section{Helsesøsters rolle}


Helsesøstrene har mange samtaler med ungdommer om både de små og store krisene. De forteller at de møter ungdommer som føler seg slitne og som opplever mye press og stress. Mange har symptomer på nedstemthet og gjennom samtalene kartlegger helsesøstrene hvordan nedstemtheten påvirker dem i hverdagen - på skole og i fritiden - og hva de trenger for å få det bedre. En av informantene sier:

«Hvis man møter en elev som har depressive symptomer, så må vi jo gå i dialog med den eleven og prøve å finne ut hva det handler om for deg, egentlig. Hvor lenge har det vart, påvirker det på noen måte andre livsfunksjoner, går det ut over søvn, matlyst, konsentrasjon på skolen ...».

Det at ungdom opplever å bli sett og hørt, at noen har tid til å lytte til dem og at de føler at de blir tatt på alvor ut ifra deres egen opplevelse av situasjonen, kan bidra til at de får det bedre. Informantene sier at ungdom kan få «ryddet opp» i bekymringstanker og, blant annet, få hjelp til å strukturere hva de bruker tiden sin til og få hjelp til å redusere det daglige programmet for en periode hvis de har behov for det.

\section{Ryddesamtaler}

Informantene forteller at ungdom med depressive symptomer ofte har problemer med å uttrykke seg og gjøre seg forstått i samvær med andre. De kan derfor bli misoppfattet av omgivelsene. I tillegg kan det være vanskelig å sette ord på og beskrive hvordan de har det. Det kan ta lang tid før ungdom føler seg komfortable nok til å ta kontakt for å snakke. En studie fra Nordlandsforskning bekrefter denne erfaringen. Informantene i studien forteller at det er vanskelig å snakke om det som er sårbart og problematisk i livene deres. Det handlet om å ikke klare å sette ord på ting, å ikke ha noen å snakke med og at de ikke makter å snakke med noen (20). 


\section{三 «Det at ungdom føler at de blir sett og hørt kan bidra til at de får det bedre.»}

Helsesøstrene sier at bare det at ungdom føler at de blir sett og hørt kan bidra til at de får det bedre. De sier at ungdom kan få hjelp til å «rydde opp» i

bekymringstanker, få hjelp til å strukturere hva de bruker tiden sin på og til å se veien videre. Det kan igjen bidra til at de opplever en større grad av mestring i hverdagen. Dette er i samsvar med andre studier, som viser til at negative tanker og fokus er en viktig ingrediens ved depressivitet.

De viser til at refleksjon som innebærer tanker, introspeksjon og kognitiv problemløsning, kan virke forebyggende (11). Det virker beskyttende å ha muligheten til å få hjelp til å se håp i en stressende livssituasjon (21). Forskning viser at empati og følelsesmessig støtte er særlig effektivt når individet er utsatt for påkjenninger og negative livshendelser. Sosial støtte kan virke som en buffer og styrker individets mestringsevne (4). Børjesson skriver at man i den helsefremmende samtalen legger vekt på hvilke faktorer som gir et menneske gode forutsetninger for å, både, beholde og fremme egen helse $(4,22)$.

\section{Konklusjon}

Studien viser at helsesøstrene møter mange elever med depressive symptomer i skolen. Nedstemtheten påvirker elevenes fysiske, psykiske og sosiale helse og deres evne til å følge opp skolen. Det kan være vanskelig å fange opp nedstemthet hos elevene, fordi ungdom er i en utviklingsalder med mye følelser og fordi de ofte skjuler at de strever. Det er derfor viktig å være oppmerksom på endringer i følelsesuttrykk og funksjonsnivå. 
Tidlige tegn på depresjon kan være at ungdom får store humørsvingninger og at de endrer atferd ved at de blir mer sint, irritabel og trist. Endret funksjonsnivå kan være at ungdom trekker seg tilbake fra det sosiale livet og at de ikke klarer å følge opp (skole)hverdagen slik de gjorde før. Tidlig intervensjon kan forhindre at psykiske vansker utvikler seg til psykiske lidelser. Elevene trenger tettere oppfølging. De trenger å bli ivaretatt både personlig, faglig og på fritiden.

Det er også viktig at alle instanser - som familie, skole, helsevesenet og eventuelt andre - samarbeider. Helsesøsters rolle i det tverrfaglige samarbeidet vil være å snakke med ungdommene, å lytte til deres opplevelse av situasjonen og hjelpe til med å «gi dem en stemme», bidra med å «rydde» hodet for kaotiske tanker og hjelpe dem til å se at veien videre kan blir bedre.

Samfunnet bør i større grad rette oppmerksomheten mot hva som er gutters uttrykk ved nedstemthet og hva gutter trenger med hensyn til trivsel og mestring $\mathrm{i}$ skolen. Videre forskning bør studere sammenhengen mellom skoleprestasjoner og psykiske vansker. Man bør finne ut hva som skal til for at alle barn og unge kan oppleve mestring i skolen og i livene sine ut fra et helhetlig perspektiv.

\section{Referanser}

1. Bakken A. Ungdata. Nasjonale resultater 2016, NOVA Rapport 8/16. Oslo: NOVA; 2016. Tilgjengelig fra: http://www.hioa.no/Om-HiOA/Senter-for-velferds-

og-

arbeidslivsforskning/NOVA/Publikasjonar/Rapporter/2016/Ungdata2016.-Nasjonale-resultater (nedlastet 25.04.2018).

2. Mykletun A, Knudsen AK, Mathiesen KS.

Psykiske lidelser i Norge: Et folkehelseperspektiv.

Oslo: Nasjonalt folkehelseinstitutt; 2009. 
3. Folkehelseinstituttet. Psykiske plager og

lidelser hos barn og unge. TOPP-studien.Oslo:

Folkehelseinstituttet; 2015.Tilgjengelig

fra: https://www.fhi.no/prosjekter/topp-studien-

prosjektbeskrivelse/ (nedlastet 15.05.18)

4. Major E, Dalgard O, Mathisen K, Nord E, Ose S, Rognerud M, og medarbeidere Bedre føre var Psykisk helse: Helsefremmende og forebyggende tiltak og anbefalinger. Oslo: Folkehelseinstituttet; 2011.

5. WHO. Depression a global public health concern. World Health Organization. 2012:3.

6. Kim-Cohen J, Caspi A, Moffitt TE, Harrington H, Milne BJ, Poulton R. Prior juvenile diagnoses in adults with mental disorder: developmental follow-back of a prospectivelongitudinal cohort. Archives of general psychiatry. 2003;60(7):709-17.

7. St. meld 47 (2008-2009)

Samhandlingsreformen -Rett behandling - på rett sted- til rett tid. Oslo: Helse- og omsorgsdepartementet; 2009

8. Holte A. Ti prinsipper for forebygging av psykiske lidelser. Tidsskrift for Norsk Psykologforening. 2012;49(7):693-5.

9. Helsedirektoratet. Nasjonal faglig retningslinje for det helsefremmende og forebyggende arbeidet $\mathrm{i}$ helsestasjon, skolehelsetjeneste og helsestasjon for ungdom. Oslo: Helsedirektoratet; 2017.

10. Jensen FE, Nutt AE. Tenåringshjernen. Hjerneforskerens overlevelsesguide til livet med ungdom. Oslo: Pax Forlag; 2016.

11. Young CC, Dietrich MS. Stressful life events, worry, and rumination predict depressive and anxiety symptoms in young adolescents. Journal of Child and Adolescent Psychiatric Nursing. 2015;28(1):35-42. 
12. Young CC, Dietrich MS, Lutenbacher M.

Brooding and reflection as explanatory of depressive symptoms in adolescents experiencing stressful life events. Issues in Mental Health Nursing. 2014;35(3):175-80.

13. Young CC, Dietrich MS. Screening for rumination and brooding may be a feasible method of identifying adolescents at high risk for depression. Journal of Pediatric Nursing. 2014;29(6):688-95.

14. Cohen JR, Young JF, Gibb BE, Hankin BL, Abela JR. Why are anxiety and depressive symptoms comorbid in youth? A multi-wave, longitudinal examination of competing etiological models. Journal of affective disorders. 2014;161:21-9.

15. Folkehelseinstituttet. Folkehelserapporten.

Oslo: Folkehelseinstituttet; 2015. Tilgjengelig fra: https://www.fhi.no/nettpub/hin/om-rapporten/omfolkehelserapporten/?termfolkehelserapporten\%202016\&h=1 (nedlastet 15.05.18)

16. Nordahl M. Menn like deprimerte som kvinner. Forskning.no; 2013. Tilgjengelig fra: https://forskning.no/psykiskelidelser/2013/09/menn-deprimerte-somkvinner (nedlastet 11.5.18).

17. Chaudhary M. Sju av ti fullfører videregående opplæring. Oslo: Statistisk sentralbyrå; 2011. Tilgjengelig fra: https://www.ssb.no/utdanning/artikler-ogpublikasjoner/sju-av-ti-fullforer-videregaaendeopplaering (nedlastet 11.5.18).

18. Jones K. Guttene takler depresjoner dårligst [internett]. NTNU; 2012. [oppdatert 15.10.12; sitert:14.05.18] Tilgengelig fra: https://forskning.no/depresjonpsykologi/2012/10/guttene-takler-depresjoner-darligst (nedlastet 16.5.18) 
19. Rasmussen ML, Haavind H, Dieserud G, Dyregrov K. Exploring vulnerability to suicide in the developmental history of young men: a psychological autopsy study. Death Stud. 2014;38(9):549-56.

20. Anvik CH, Gustavsen A. Ikke slipp meg! Unge, psykiske helseproblemer, utdanning og arbeid. Bodø: Nordlandsforskning; 2012.

21. Visser PL, Loess P, Jeglic EL, Hirsch JK. Hope as a Moderator of Negative Life Events and Depressive Symptoms in a Diverse Sample. Stress \& Health: Journal of the International Society for the Investigation of Stress. 2013;29(1):82-87.

22. Børjesson M. Motivasjon, mestring og medfølelse. Om å samtale med tenåringer. Oslo: Gyldendal Norsk forlag; 2013. 